Tsaqofiya : Jurnal Pendidikan Bahasa dan Sastra Arab

Vol. 3 No. 1, 2021, 61-75

P-ISSN : 2685-7022, E-ISSN : 2685-7103

DOI: $10.21154 /$ tsaqofiya.v3i1.68

\title{
Struktur Kepribadian Tokoh Iryân dalam Novel al-Rajulu al-Lazî Âmana Karya Najib al-Kailani (Analisis Psikologi Sigmund Freud)
}

\author{
Ali Nur Yasin, Darisy Syafaah \\ Institut Agama Islam Negeri Tulungagung \\ Alinuryasin819@gmail.com
}

\section{Abstract}

The purpose of this study is to determine the personality structure of the Iryâ $n$ character in the novel Al-Rojulu Al-Lazî Âmana by using Sigmund Freud's theory. The research method used is descriptive qualitative with analysis content techniques descriptive analysis. The results of this study illustrate that there are many findings about the personality structure of the character Iryâ $n$ in the novel Al-Rojulu Al-Laz î Amana. There are eight forms of Id which are instincts to meet sexual needs and also instincts to gain comfort in life. There are also 6 forms of Ego which are responsible for decision making and reasoning. The superego in Iryân consists of three forms that connect Iryân's reasoning with conscience, morality and religious norms. Overall, the character Iryân fits into the form of Id. Although not all forms of Id that exist in Iryân occur.

Keywords: personality structure of figures Iryân, novel Al-Rojulu Al-Lazî Âmana, psychology of literature

\section{Abstrak}

Tujuan penelitian ini adalah untuk mengetahui struktur kepribadian pada tokoh Iryân dalam novel Al-Rojulu Al-Lazî Âmana dengan menggunakan teori Sigmund Freud. Metode penelitian yang digunakan adalah kualitatif deskriptif dengan teknik analisis data deskriptif analisis. Hasil penelitian ini menggambarkan bahwa terdapat banyak penemuan tentang struktur kepribadian pada tokoh Iryân dalam novel Al-Rojulu Al-Lazî Âmana. Terdapat delapan bentuk Id yang berupa naluri untuk memenuhi kebutuhan seks dan juga bentuk naluri untuk memperoleh kenyamanan hati dalam hidup. Ditemukan juga 6 bentuk Ego yang bertugas dalam pengambilan keputusan dan juga penalaran. Superego dalam Iryân berjumlah tiga bentuk yang menghubungkan penalaran Iryân dengan hati nurani, moralitas serta norma agama. Secara keseluruhan tokoh Iryân lebih codong ke dalam bentuk Id. Meski tidak semua bentuk Id yang ada dalam diri Iryân terjadi.

Kata Kunci: struktur kepribadian tokoh Iryân, novel Al-Rojulu Al-Lazî Âmana, psikologi sastra 


\section{Pendahuluan}

Karya sastra merupakan produk dari suatu proses kejiwaan dan pemikiran pengarang saat berada dalam kondisi setengah sadar (subconcious), kemudian setelah mendapatkan gambaran bentuk maka dituangkan secara sadar (conscious) menjadi suatu karya. ${ }^{1}$ Karya sastra dapat dipahami sebagai bentuk komunikasi alam bawah sadar pengarang yang dikelola menjadi berbagai imajinasi kemudian dijadikan berbagai bentuk karya sastra yang dapat dinikmati oleh pembaca. Terdapat tiga jenis karya sastra yaitu, prosa, puisi dan drama. Diantara ketiga jenis tersebut terdapat prosa yang panjang yaitu novel. Novel dapat dipahami sebagai karya sastra yang menceritakan peristiwa atau pengalaman lahir dan batin tokoh, yang dapat mengubah kehidupan tokoh cerita di dalamnya. ${ }^{2}$

Dalam artikel penelitian ini, penulis akan membahas novel yang berjudul $\mathrm{Al}$ Rojulu Al-Lazî Âmana karya Najib al-Kailani. Novel ini diterbitkan di Lebanon pada tahun 2005. Seorang lelaki yang beriman atau dalam bahasa Arab disebut Al-Rojulu Al-Lazî Âmana merupakan novel yang mengisahkan tentang perjalanan seorang pemuda yang merasa tidak nyaman dengan agama dan lingkungan hidupnya. Terlahir dari keluarga Katolik yang taat, menyebabkan ia sangat memperhatikan keadaan Roma yang jauh dari ajaran Kristus. Hatinya bergejolak dan alam sadarnya menuntut untuk mencari kedamaian dan lingkungan kehidupan baru yang membuat dirinya nyaman. Berbagai jenis cinta yang ia berikan kepada wanita tidak membuat dirinya mendapatkan kedamaian abadi. Sebuah konser band di Dubai membuka jalan bagi Iryân untuk mulai mengenal Islam. Ia pun memutuskan untuk memberikan cinta yang sepenuhnya kepada sang kuasa dan agama barunya. Novel ini sarat akan pesan untuk kembali kepada agama Islam yang benar, baik sacara lahir maupun batin. ${ }^{3}$

Novel Al-Rojulu Al-Lazî Âmana merupakan salah satu karya fenomenal dari seorang sastrawan Islam terkenal asal Mesir yang bernama Najib al-Kailani. Dilahirkan pada 10 juni 1931 masehi, Najib al-Kailani termasuk kedalam sastrawan kontemporer. ${ }^{4}$ Beliau tercatat pernah mendapat beberapa penghargaan bergengsi melalui karya-karyanya yang telah diterjemahkan menjadi beberapa bahasa. ${ }^{5}$ Najib

\footnotetext{
${ }^{1}$ Suwadi Endraswara, Metode Penelitian Psikologi Sastra (Yogyakarata: Medpress,2008), hal. 7.

${ }^{2}$ Alfian Rokhmansyah, Studi dan Pengkajian Sastra, (Yogyakarta : Graha Ilmu, 2014), hal. 13.

${ }^{3}$ Najib al-Kailani, al-Rojulu al-Laz/i A<mana, (Lebanon : Resalah, 2005), hal

4 Abdullah bin Shalih al-Arini, al-Ittijah al-Islamy fi< A'mal Najib al-Kailany al-Qosasiyyah, (Riyad : Dar Kunuz Islibiya, 2005), hal. 1

${ }^{5}$ al-Arini, hal. 29.
} 
al-Kailani pernah beberapa kali dijebloskan ke dalam penjara. Hal ini dikarenakan beliau tergabung ke dalam kelompok agama Ikhwanul Muslimin'6 yang berbeda pandangan politik dengan pemerintah Mesir. ${ }^{7}$ Najib al-Kailani juga menggunakan karya sastra sebagai media dakwah. Sehingga di dalam karya-karya beliau terdapat nilai-nilai keislaman dan juga perlawanan akan ketidakadilan.

Najib al-Kailani merupakan salah satu sastrawan yang produktif. Beliau memiliki banyak karya seperti novel, cerita pendek, syiir, dan juga drama. Beberapa karya novel beliau adalah Ard\} al-Anbiyâ', al-Lazî Yahtariqun, Rihlah ila Allâh, Lail wa al-Qud\{ban, Al-Rojulu Al-Lazî Âmana, dll. ${ }^{8}$ Novel yang disebutkan terakhir merupakan novel yang akan penulis teliti tentang psikologis tokoh utama di dalamnya. Novel AlRojulu Al-Lazî Âmana merupakan novel yang selesai penulisannya pada 11 Oktober 1993 di Mesir. Novel ini memiliki ketebalan 127 halaman dan pernah beberapa kali diterbitkan. Penulis mendapatkan novel ini terbitan resalah pada tahun $2005 .{ }^{9}$

Dalam novel Al-Rojulu Al-Lazî Âmana mengisahkan perjalanan seorang lelaki bernama Iryân dalam mendapatkan ketenangan dan kenyamanan dalam hidupnya. Lahir di kota Roma, Italia dengan segala kemewahan serta kemajuan kotanya tidaklah membuat Iryân memperoleh kebahagiaan. Kehidupan dan kondisi sosial di Roma sangat kontras dengan apa yang selalu ayahnya ajarkan sejak kecil. Agama bukanlah suatu hal penting di Roma, melainkan penyaluran nafsu manusia yang dijadikan gaya hidup oleh sebagian masyarakat Roma. Ia berangan-angan ingin pergi ke daerah timur untuk melihat bagaimana kehidupan di sana. Alangkah terkejutnya Iryân ketika sampai di Dubai saat melihat kondisi sosial dan juga budaya mereka. Masyarakat Dubai tidaklah menghilangkan agama dalam gaya hidupnya. Percintaan Iryân dengan seorang penari kafe bernam Syams mendekatkan ia ke dalam agama Islam. Meski ia mendapat banyak sekali tekanan bahkan ancaman pembunuhan, ia tetap bersikeras untuk meninggalkan agama lamanya dan masuk ke dalam agama barunya yaitu Islam. Bagai seseorang yang kelaparan, Iryân sangat terobsesi dan tekun dalam mendalami segala aspek tentang agama barunya. Selang beberapa bulan belajar, ia pun

\footnotetext{
${ }^{6}$ Gerakan islam yang aktif menerapkan dan mempromosikan ajaran Islam berdasarkan Qur'an dan Sunnah secara ketat dalam kehidupan umatnya. Didirikan Hasan al-Banna yang dikenal sebagai pembimbing agung oleh pengikutnya. Organisasi ini berusaha untuk menentang rezim-rezim negeri muslim yang sekuler. Musyarif, "Hasan al-Banna al-Ikhwan al-Muslimun : Studi Pemikiran dan Gerakan Dakwah," Jurnal Kuriositas 17, No. 1 (2017): 91 - 104

7 al-Arini, hal. 14.

${ }^{8}$ Al-Arini, hal. 19-20.

${ }^{9}$ al-Kailani, hal. 127.
} 
memutuskan untuk berdakwah ke daerah India bersama pendakwah lain yang telah lama menetap di sana.

Alur cerita dalam novel tersebut lebih banyak membahas kondisi psikologis tokoh. Ilmu psikologi yang digunakan untuk menganalis sastra dinamakan psikologi sastra. Psikologi sastra merupakan telaah karya sastra yang diyakini mencerminkan proses dan aktifitas kejiwaan. ${ }^{10}$ Karya-karya sastra memungkinkan ditelaah melalui pendekatan psikologi karena karya satra menampilkan watak tokoh, walaupun semua hanya imajinatif akan tetapi dapat menampilkan berbagai problem psikologis. Dalam istilah psikologi sastra terdapat empat pengertian, yakni studi psikologi pengarang sebagai tipe atau pribadi, kajian proses kreatif, dampak sastra terhadap pembaca dan hukum psikologi yang diterapkan pada karya sastra. ${ }^{11}$ Istilah yang terakhir ini yang akan penulis gunakan dalam menganalisis tokoh dalam novel tersebut.

Analisis psikologis pada penelitian ini menggunakan teori Sigmund Freud. Menurut Freud, Tingkah laku merupakan hasil dari konflik dan rekonsiliasi ketiga sistem kepribadian. Faktor-faktor yang memengarui kepribadian seseorang adalah faktor historis masa lampau dan juga faktor kontemporer. Pembagian psikisme dalam struktur kepribadian menurut Freud terdapat tiga macam, yaitu Id, Ego, dan Superego. Id terletak di bagian taksadar, Ego terletak diantara alam sadar dan tak sadar sedangkan Superego terletak diantara sadar dan tak sadar. Ketiga hal tersebut saling berhubungan dan juga saling melengkapi. ${ }^{12}$

Id merupakan energi psikis dan naluri yang menekan untuk memenui kebutuhan dasar sejak lahir13, seperti makan, seks, menolak rasa sakit dan tidak nyaman. $I d$ berada di alam bawah sadar dan tidak memiliki kontak realitas. $I d$ selalu menggunakan prinsip kesenangan dan menghindari ketidaknyamanan. ${ }^{14}$ Tidak bisa dibayangkan jikalau semua diri manusia hanya terdiri dari Id semata, mungkin akan terjadi pengumbaran nafsu dan keinginan tanpa adanya yang menekan.

Ego berada di alam sadar dan tak sadar. Tugas Ego adalah memberi tempat pada fungsi mental, seperti: penalaran, penyelesaian masalah, dan mengambil keputusan atas Id yang telah muncul. Ego berkutat dengan masalah realitas. Ego

\footnotetext{
${ }^{10}$ Albertine Minderop, Psikologi Sastra, (Jakarta : Pustaka Obor, 2018), hal. 54-56.

11 Minderop, hal. 20-21.

12 Sigmund Freud, al-Mujaz fii Tahlil al-Nafsy, (Maktabah al-Usroh, 2000), hal. 26. Terjemahan

13 Minderop, hal. 22.

${ }^{14}$ Freud, hal. 26.
} 
menolong manusia untuk mempertimbangkan apakah ia dapat memuaskan diri tanpa mengakibatkan kesulitan dan juga masalah terhadap diri sendiri. Karenanya, Ego merupakan pimpinan utama dalam kepribadian yang bertugas sebagai sopir kepribadian diri seseorang.

Superego mengacu dan berhubungan dengan moralitas dalam kepribadian. Superego mengenal istilah nilai baik dan buruk. Superego tidak mempertimbangan realitas karena tidak terdapat dalam hal-hal realistik. Bisa dikatakan Superego itu cerminan norma-norma, baik norma agama maupun hukum adat. Jikalau impuls Id keluar, maka yang bertugas sebagai penyaring dan pembanding adalah Superego. ${ }^{15}$

Penelitian seputar psikologi sastra pada novel sudah banyak dilakukan. Seperti halnya penelitian yang dilakukan oleh Riztikha Khairani dengan judul "Analisis Klasifikasi Emosi Cinta Tokoh Laylâ dalam Novel al-Arwâhu al-Mutawarridah karya Khalil Gibran (Kajian Psikologi Sastra)". Penelitian tersebut berisi analisis Emosi tokoh Laylâ yang dibenturkan dengan teori klasifikasi Emosi David Krech. ${ }^{16}$

Penelitian yang dilakukan oleh Rahimal Khair dengan judul "Arketipe Ketaksadaran Tokoh Faris dan Inayah dalam novel Lail wa al-Qud\{ban karya Najib AlKailani". Penelitian ini berisi tentang analisis konflik psikologis yang menyebabkan perubahan sifat tokoh Faris dan Inayah dalam bertindak. Penelitian ini menggunakan teori psikologi Carl Gustav Jung. ${ }^{17}$

Penelitian yang dilakukan oleh Nurjaliyah Siompu dengan judul "Tagyîr Syakhs\{iyah al-Asâsy fî al-Riwayah Al-Rojulu Al-Lazî Âmana li Najib al-Kailani (Dirasah Tah\{liliyah Sikulujiyah Adabiyah)". Penelitian ini berisi tentang analisis perubahan tingkah laku tokoh utama dengan menggunakan teori Sigmund Freud. Berbeda dengan penelitian yang akan penulis lakukan, penelitian yang dilakukan oleh Nurjaliyah fokus kepada perubahan tingkang laku tokoh utama sedangkan penelitian yang akan dilakukan dibawah ini berfokus pada struktur kepribadian (Id, Ego dan Superego) tokoh utama. ${ }^{18}$

15 Minderop, hal. 22.

16 Riztikha Khairani, “Analisis Klasifikasi Emosi Cinta Tokoh Layla> dalam Novel al-Arwa>hu al-Mutawarridah karya Khalil Gibran (Kajian Psikologi Sastra)," Jurnal Tsaqofiya-Jurnal Pendidikan Bahasa dan Sastra Arab 2 No.2 Juli 2020: 1-14.

17 Rahimal Khair, "Arketipe Ketaksadaran Tokoh Faris dan Inayah dalam novel Lail wa Qudbhan karya Najib Al-Kalani," Jurnal Arabiyatuna-Jurnal Bahasa Arab 4 No.1 Mei 2020: 49-68.

18 Nurjaliyah Siompu, "Tagyi>r Syakhs $\{$ iyah al-Asa>sy fi> al-Riwayah Al-Rojulu Al-Laz|i A<mana li Najib al-Kailani (Dirasah Tah\{liliyah Sikulujiyah Adabiyah)”, 2015. 
Berdasarkan tinjauan diatas, penelitian dengan judul " Struktur Kepribadian Tokoh Iryân dalam Novel Al-Rojulu Al-Lazî Âmana karya Najib al-Kailani (Analisis Psikologi Sigmund Freud)" belum pernah dilakukan. Terdapat berberapa penelitian yang menjadikan novel tersebut menjadi obyek penelitin akan tetapi teori yang digunakan memakai tokoh psikologi yang lain.

Sebagaimana penjelasan diatas, penulis bermaksud untuk meneliti novel AlRojulu Al-Lazî Âmana karya Najib al-Kailani menggunakan teori Sigmund Freud. Adapun hal-hal yang menarik dari novel tersebut merupakan banyaknya alur yang berhubungan kondisi psikologi tokoh. Pertentangan batin, penolakan kan keadaan, cinta tak terbalas, perjalanan menemukan agama baru merupakan sebagian dari beberapa keadaan yang membuat penulis tertarik untuk membedah novel tersebut. Penulis akan fokus menguak tentang Id, Ego dan Superego dari tokoh utama yaitu Iryân.

Adapun alasan penulis memilih melakukan penelitian ini adalah untuk mengungkap struktur kepribadian yang ada dalam tokoh utama serta hubungannya dengan ketiga bagian-bagian psikisme. Faktor yang melatarbelakangi pemilihan novel adalah alur dan juga penokohan yang sangat menarik untuk diteliti. Terdapat juga banyak pesan moral di dalam novel tersebut. Nilai keislaman juga kental sekali dengan cerita yang ada. Manfaat bagi pembaca dan juga peneliti adalah mengetahui psikologi dari tokoh utama menggunakan teori Sigmund Freud.

\section{Metode}

Metode yang digunakan dalam penelitian ini adalah metode deskriptif kualitatif. Dikatakan deskriptif karena dalam penelitian ini mendeskripsikan data berdasarkan kenyataan-kenyataan secara obyektif sesuai dengan data yang ditemukan. Dikatakan kualitatif karena dalam menjelaskan konsep-konsep yang berkaitan satu sama lain dengan menggunakan kata-kata atau kalimat bukan angka statistik. ${ }^{19}$ Jenis penelitian ini termasuk kepustakaan (library research) yang didukung oleh referensi novel Al-Rojulu Al-Lazî Âmana karya Najib al-Kailani dan buku, jurnal, serta skripsi yang berhubungan dengan penelitian ini.

${ }^{19}$ Burhan Nurgiantoro, Teori Pengkajian Fiksi, (Yogyakarta : Gajah Mada University, 2009), hal. 
Penelitian ini berfokus pada struktur kepribadian tokoh utama yang berupa tulisan dalam novel Al-Rojulu Al-Lazî Âmana karya Najib al-Kailani. Adapun data pada penelitian ini adalah kalimat-kalimat yang berhubungan dengan psikologi tokoh Iryân dalam novel Al-Rojulu Al-Lazî Âmana. Penulis menggunakan sumber data primer dalam penelitian ini, yaitu kalimat dalam novel Al-Rojulu Al-Lazî Âmana karya Najib al-Kailani. Metode pengumpulan data yang digunakan dalam penelitian ini adalah teknik dokumentasi. ${ }^{20}$ Teknik ini dijalankan dengan menelusuri dan membaca novel Al-Rojulu Al-Lazî Âmana secara berulang-ulang dengan teliti sampai ditemukan kutipan-kutipan kalimat yang mengandung Id, Ego, dan juga Superego dari tokoh Iryân.

Metode analisis data dalam menganalisi novel Al-Rojulu Al-Lazî Âmana dengan menggunakan teori deskriptif analisis, ${ }^{21}$ Teknik analisis data dalam penelitian ini melalui beberapa tahapan, yaitu tahap pertama penulis membaca novel Al-Rojulu AlLazî Âmana dengan teliti dan juga komprehensif. Tahap kedua penulis menentukan kalimat-kalimat yang mengandung struktur kepribadian Sigmund Freud. Tahap ketiga penulis menentukan dan juga mengkategorikan kalimat yang mengandung ungkapan Id, Ego, dan Superego. Tahap keempat penulis menyimpulkan bagaimana psikologis tokoh utama berdasarkan temuan pada poin 3.

\section{Pembahasan}

Dalam penelitian ini, penulis mengumpulkan data dan juga mengklasifikasikan kalimat yang telah ditemukan ke dalam tingkatan psikis, yaitu Id, Ego, dan Superego yang berhubungan tokoh Iryân. Iryân merupakan tokoh utama dalam novel Al-Rojulu Al-Lazî Âmana. Sebagai tokoh utama jelas Najib al-Kailani menjadikannya sebagai poros cerita dan membuat kepribadiannya menjadi menarik untuk diteliti.

\begin{tabular}{|c|c|c|c|}
\hline NO & Kutipan Novel & $\begin{array}{l}\text { Kategori } \\
\text { Psikis }\end{array}$ & Penjelasan \\
\hline 1 & قيل له : إذهب يا "إريان" إلى الشرق، بلاد السحر و ألخال & Id & $\begin{array}{l}\text { Naluri untuk menolak } \\
\text { rasa tidak nyaman dan }\end{array}$ \\
\hline
\end{tabular}

20 Mahi M. Hikmat, Metode Penelitian: Dalam Perspektif Ilmu Komunikasi dan Sastra, (Yogyakarta : Graha Ilmu, 2011), hal. 83

${ }^{21}$ Nyoman Kuta Ratna, Teori, Metode, Teknik Penelitian Sastra, (Yogyakarta: Pustaka Pelajara, 2015), hal. 47-48. 


\begin{tabular}{|c|c|c|c|}
\hline & 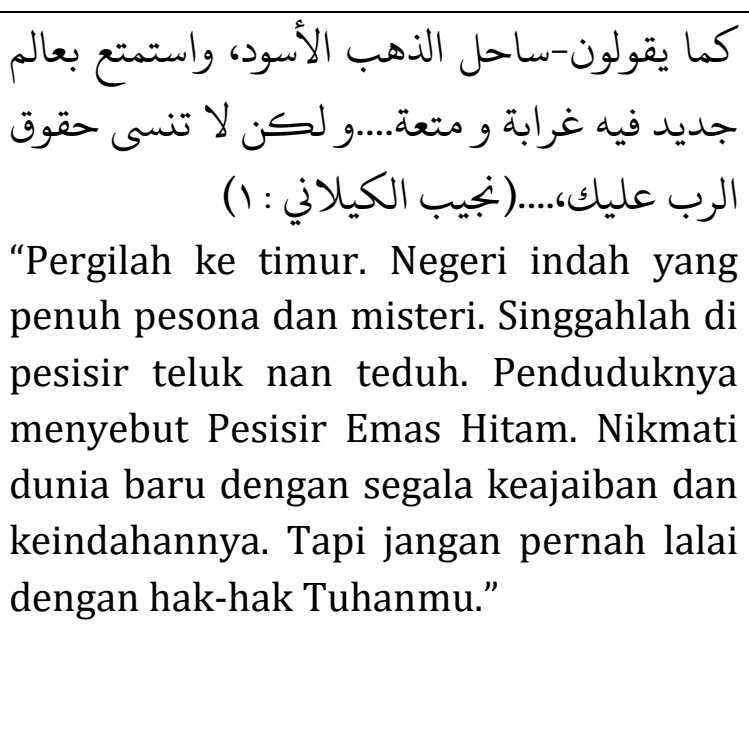 & & $\begin{array}{l}\text { berusaha mencari hal } \\
\text { yang membuatnya } \\
\text { nyaman dalam } \\
\text { hidupnya. } \\
\text { Dalam hal ini Iryân } \\
\text { tidak mendapatkan } \\
\text { kenyamanan dengan } \\
\text { kota Roma dan segala } \\
\text { sesuatu di dalamnya. } \\
\text { Tanpa sadar ia ingin } \\
\text { untuk pergi ke dunia } \\
\text { timur dan menemukan } \\
\text { kenyamanan disana. }\end{array}$ \\
\hline 2 & 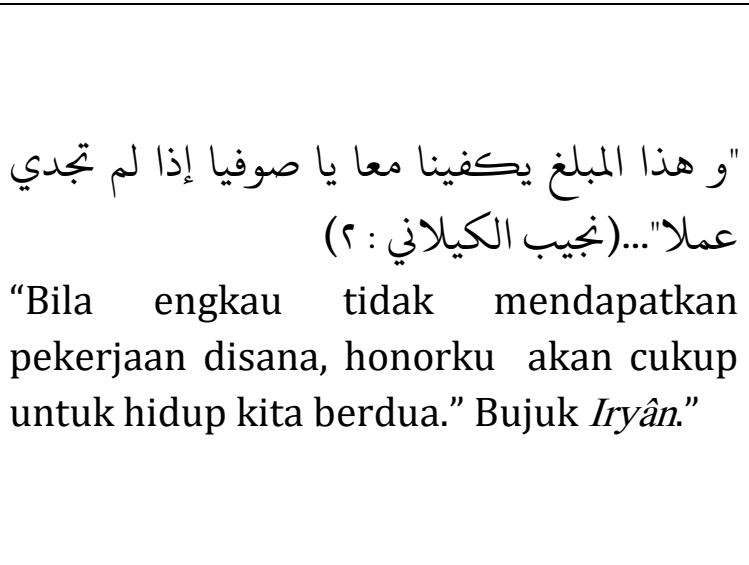 & $I d$ & $\begin{array}{l}\text { Naluri untuk memenuhi } \\
\text { kebutuhan seks. } \\
\text { Iryân mengajak } \\
\text { kekasihnya Su>fiyâ } \\
\text { untuk segera } \\
\text { melangsungkan } \\
\text { pernikahan.Ia berusaha } \\
\text { mengajak Su>fiyâ } \\
\text { untuk ikut dengannya } \\
\text { ke Dubai. }\end{array}$ \\
\hline 3 & 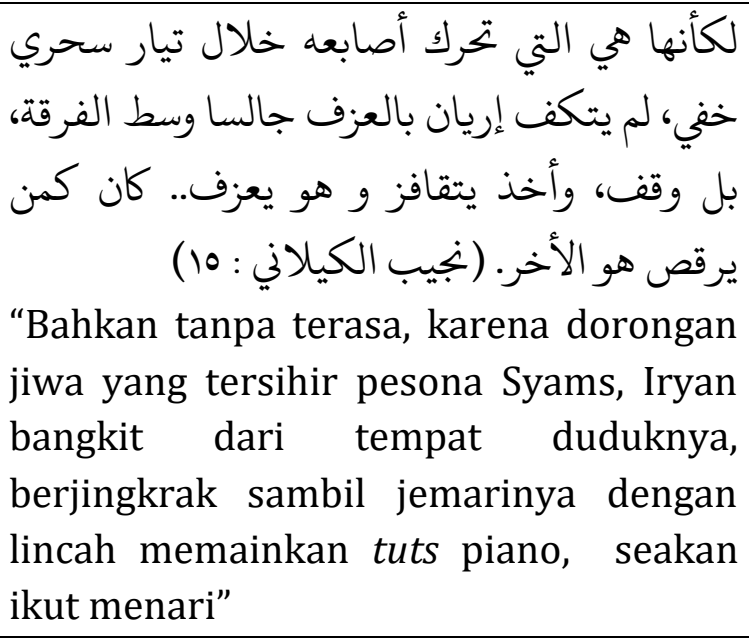 & Id & $\begin{array}{l}\text { Naluri untuk memenuhi } \\
\text { kebutuhan seks. } \\
\text { Iryân yang melihat } \\
\text { tarian Syams tanpa } \\
\text { sadar langsung bangkit } \\
\text { dari tempat duduknya } \\
\text { dan langsung menari } \\
\text { bersamanya. }\end{array}$ \\
\hline 4 & 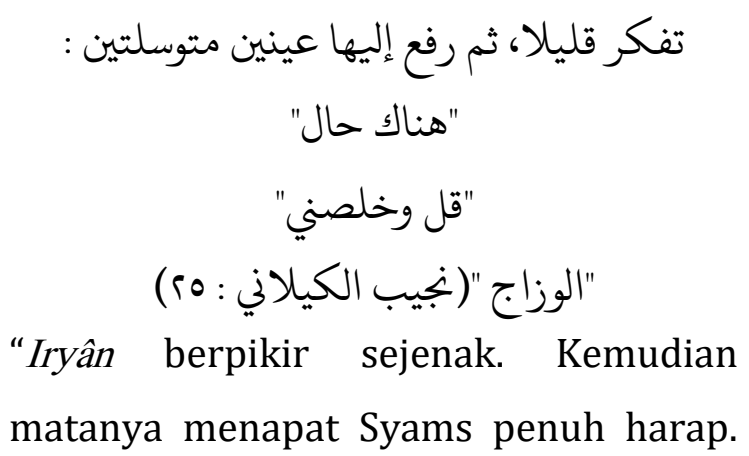 & $I d$ & $\begin{array}{l}\text { Naluri untuk memenuhi } \\
\text { kebutuhan seks. } \\
\text { Seperti sebelumnya, } \\
\text { jikalau mencintai } \\
\text { seseorang, Iryân selalu } \\
\text { berupaya untuk segera } \\
\text { menikah dengan orang } \\
\text { yang dicintai. Inilah }\end{array}$ \\
\hline
\end{tabular}




\begin{tabular}{|c|c|c|c|}
\hline & $\begin{array}{l}\text { Kemudian matanya menatap Syams } \\
\text { penuh harap. Keluar nada ragu dari } \\
\text { mulutnya, "hanya ada satu jalan keluar," } \\
\text { "Katakanlah!" bentak tak sabar. } \\
\text { "Menikah." }\end{array}$ & & $\begin{array}{l}\text { awal mula pertemuan } \\
\text { Iryân dengan agama } \\
\text { Islam. }\end{array}$ \\
\hline 5 & 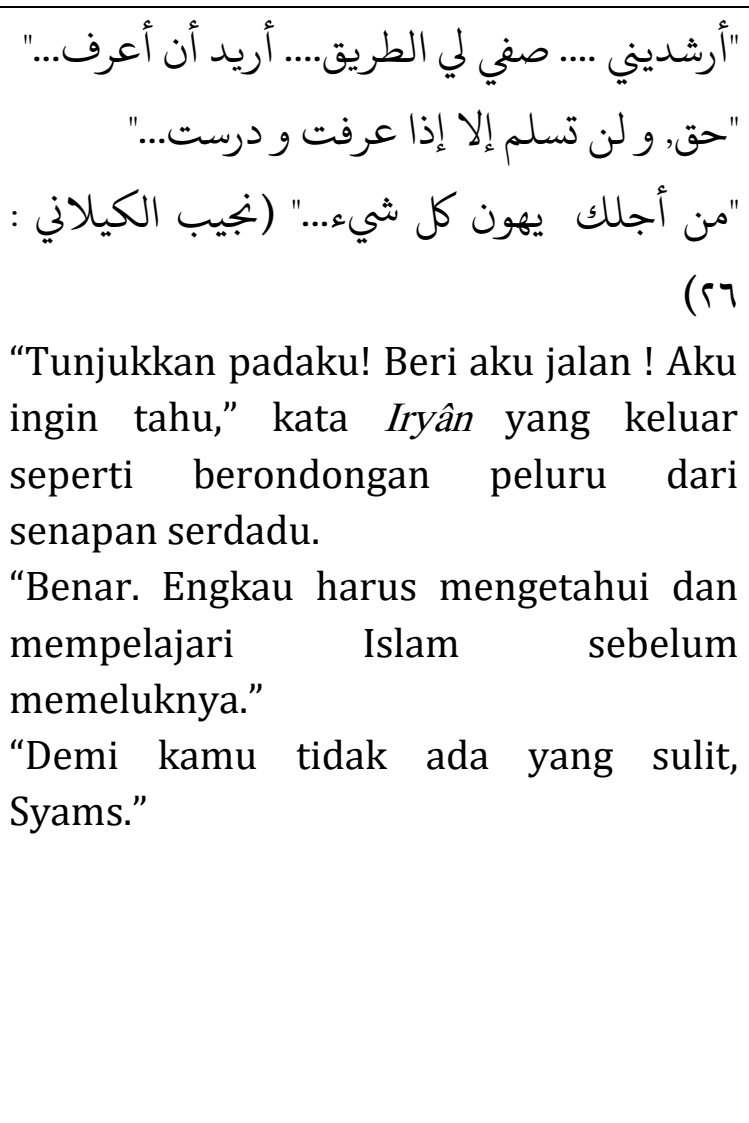 & Id & $\begin{array}{c}\text { Naluri untuk memenuhi } \\
\text { kebutuhan seks. } \\
\text { Keinginan Iryân untuk } \\
\text { menikahi Syams } \\
\text { membuatnya rela } \\
\text { melakukan apapun, } \\
\text { termasuk untuk } \\
\text { mempelajari Islam dan } \\
\text { menjadi seorang } \\
\text { muallaf. Meski awal } \\
\text { perkenalan ia dengan } \\
\text { Islam dikarenakan } \\
\text { wanita, namun } \\
\text { akhirnya ia pun masuk } \\
\text { Islam tanpa dorongan } \\
\text { Syams. Perasaan } \\
\text { nyaman setelah } \\
\text { mempelajari Islam } \\
\text { membuatnya menjadi } \\
\text { seorang muallaf. }\end{array}$ \\
\hline 6 & 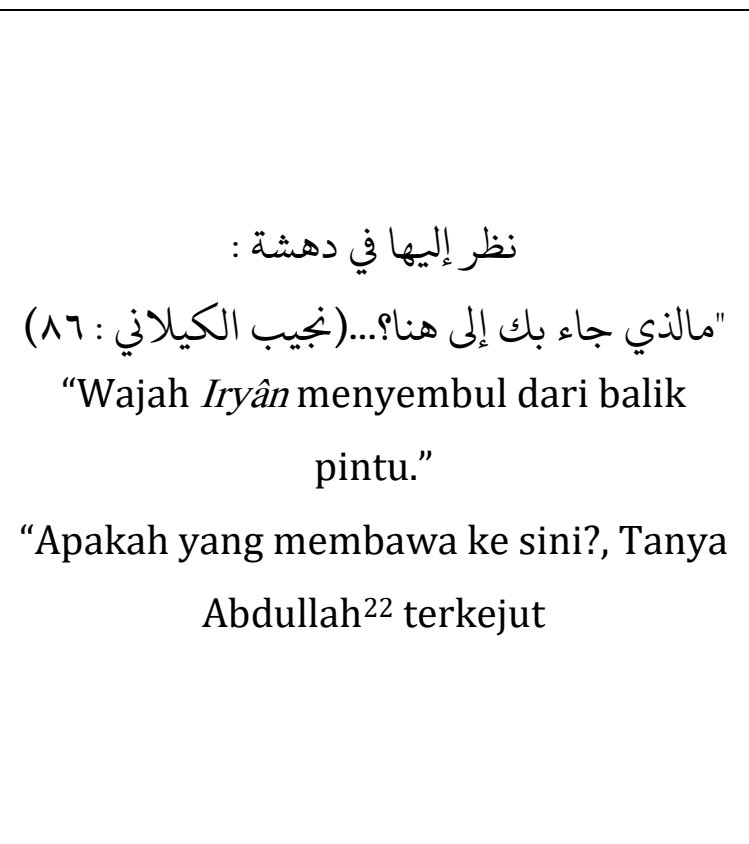 & Id & $\begin{array}{c}\text { Naluri untuk memenuhi } \\
\text { kebutuhan yaitu } \\
\text { menolak rasa tidak } \\
\text { nyaman. } \\
\text { Setelah memutuskan } \\
\text { untuk masuk Islam. } \\
\text { Iryân berusaha untuk } \\
\text { menjalankan ajaran } \\
\text { Islam dengan sebaik- } \\
\text { baiknya. Karenanya ia } \\
\text { merasa tidak nyaman } \\
\text { dengan kehadiran } \\
\text { Syams yang } \\
\text { menggunakan pakaian } \\
\text { terbuka di tempat ia }\end{array}$ \\
\hline
\end{tabular}

22 Nama Irya $>$ n setelah ia menjadi muallaf 


\begin{tabular}{|c|c|c|c|}
\hline & & & tinggal. \\
\hline 7 & 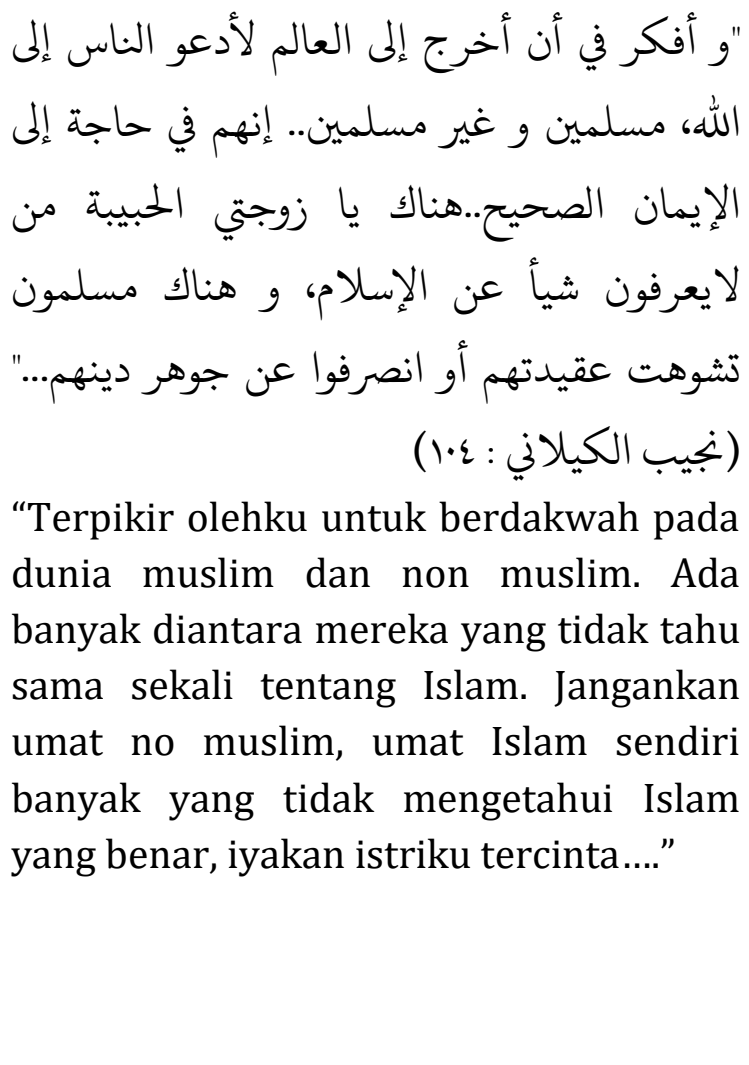 & Id & $\begin{array}{c}\text { Naluri untuk memenuhi } \\
\text { kebutuhan yaitu } \\
\text { mendapatkan } \\
\text { kenyamanan. } \\
\text { Setelah mempelajari } \\
\text { Islam bersama Syekh } \\
\text { Id }^{23} \text {, Iryân mendapat } \\
\text { dorongan untuk } \\
\text { berdakwah dan } \\
\text { mengajarkan Islam ke } \\
\text { seluruh dunia. Ini } \\
\text { merupakan panggilan } \\
\text { jiwanya karena } \\
\text { menganggap bahwa } \\
\text { banyak orang yang } \\
\text { sama sekali tidak } \\
\text { mengetahui Islam } \\
\text { bahkan dari golongan } \\
\text { muslim itu sendiri. }\end{array}$ \\
\hline 8 & $\begin{array}{c}\text { ".... كان عبد الله يتعجل الرحيل إلى الdند..." (نجيب الكيلاني : سזا ( Keinginan Abdullah untuk pergi ke } \\
\text { "India semakin tak tertahankan...” }\end{array}$ & Id & $\begin{array}{l}\text { Naluri untuk memenuhi } \\
\text { kebutuhan yaitu } \\
\text { mendapatkan } \\
\text { kenyamanan. } \\
\text { Mengetahui bahwa } \\
\text { banyak murid Syekh Id } \\
\text { yang sedang } \\
\text { berdakwah ke India, } \\
\text { Iryân sangat } \\
\text { berkeinginan untuk } \\
\text { segera menyusul } \\
\text { mereka. Padahal pada } \\
\text { saat yang sama istrinya } \\
\text { Maisu>n }{ }^{24} \text { sedang } \\
\text { dalam keadaan hamil. }\end{array}$ \\
\hline 9 & $\begin{array}{c}\text { "سوف أرحل يا صوفيا"..(نجيب الكيلاني : } 1 \text { "Aku akan pergi, Sūfiyâ,” } \\
\text { "A }\end{array}$ & Ego & $\begin{array}{l}\text { Bentuk Ego yang terjadi } \\
\text { ketika Iryân } \\
\text { memutuskan untuk } \\
\text { semakin mantap pergi } \\
\text { meninggalkan Roma. }\end{array}$ \\
\hline
\end{tabular}

${ }^{23}$ Syeikh yang membimbing dan mengajari Irya $>n$ tentang Islam

${ }^{24}$ Seorang wanita Dubai keturunann Suriah yang dipilih langsung oleh Syekh Id untuk menjadi istri Irya $>\mathrm{n}$ 


\begin{tabular}{|c|c|c|c|}
\hline & & & $\begin{array}{c}\text { Hal ini didukung } \\
\text { dengan band tempat ia } \\
\text { bekerja akan pentas ke } \\
\text { Dubai. Dunia timur } \\
\text { yang selama ini } \\
\text { menjadi misteri dalam } \\
\text { benak Iryân. Inilah } \\
\text { kesempatan Iryân } \\
\text { untuk mengetahui } \\
\text { dunia timur serta seluk } \\
\text { beluk didalamnya. }\end{array}$ \\
\hline 10 & 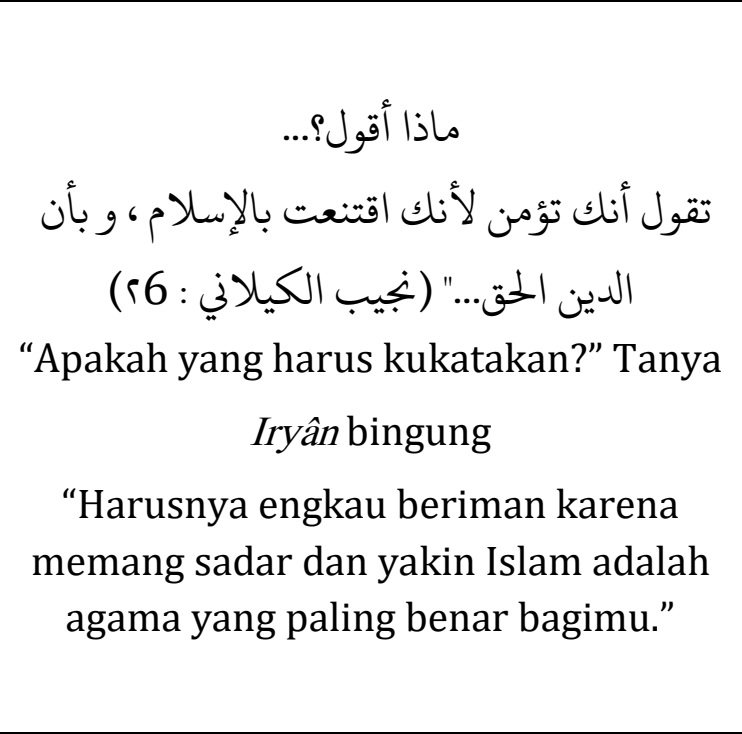 & Ego & $\begin{array}{c}\text { Bentuk Ego yang } \\
\text { berupa pengambilan } \\
\text { keputusan. Iryan yang } \\
\text { sangat ingin } \\
\text { menjadikan Syams } \\
\text { sebagai istri } \\
\text { berkeinginan untuk } \\
\text { mempelajari Islam } \\
\text { demi Syams. Inilah Ego } \\
\text { sebagai dasar sebelum } \\
\text { Iryân mulai menekuni } \\
\text { Islam dengan } \\
\text { sebenarnya }\end{array}$ \\
\hline 11 & 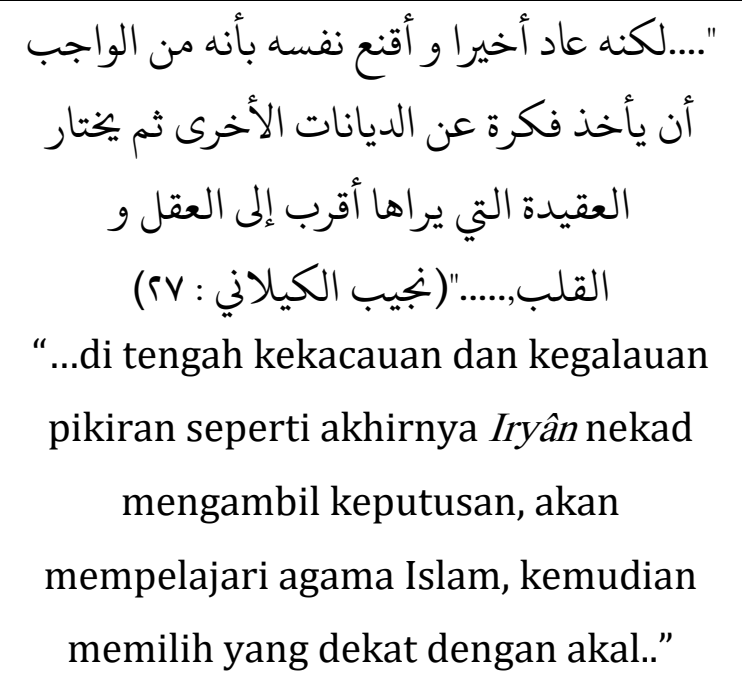 & Ego & $\begin{array}{c}\text { Bentuk Ego yang } \\
\text { berupa pengambilan } \\
\text { keputuan. Ditengah } \\
\text { kekacauan hatinya, } \\
\text { Iryân memutuskan } \\
\text { mempelajari agama } \\
\text { Islam. Ia menganggap } \\
\text { belajar agama Islam } \\
\text { sama dengan } \\
\text { mempelajari Ilmu yang } \\
\text { lain. }\end{array}$ \\
\hline 12 & 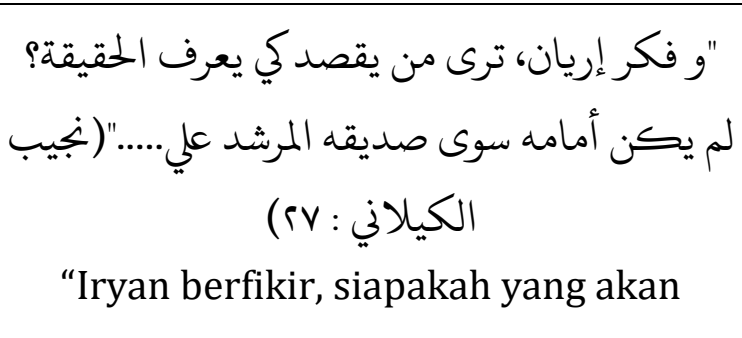 & Ego & $\begin{array}{l}\text { Bentuk Ego berupa } \\
\text { penyelesaian masalah. } \\
\text { Setelah memutukan } \\
\text { untuk mulai } \\
\text { mempelajari agama } \\
\text { Islam, Iryân dilanda }\end{array}$ \\
\hline
\end{tabular}




\begin{tabular}{|c|c|c|c|}
\hline & $\begin{array}{c}\text { menunjukan padanya untuk mengetahui } \\
\text { Islam?. Tiba" ia teringat Ali, kawan } \\
\text { akrabnya..." }\end{array}$ & & $\begin{array}{c}\text { kebingungan, kepada } \\
\text { siapa belajar agama?. } \\
\text { Mengingat ia hanyalah } \\
\text { seorang pendatang } \\
\text { yang belum tahu } \\
\text { tentang agama Islam } \\
\text { dan para pemuka } \\
\text { agama setempat. }\end{array}$ \\
\hline 13 & 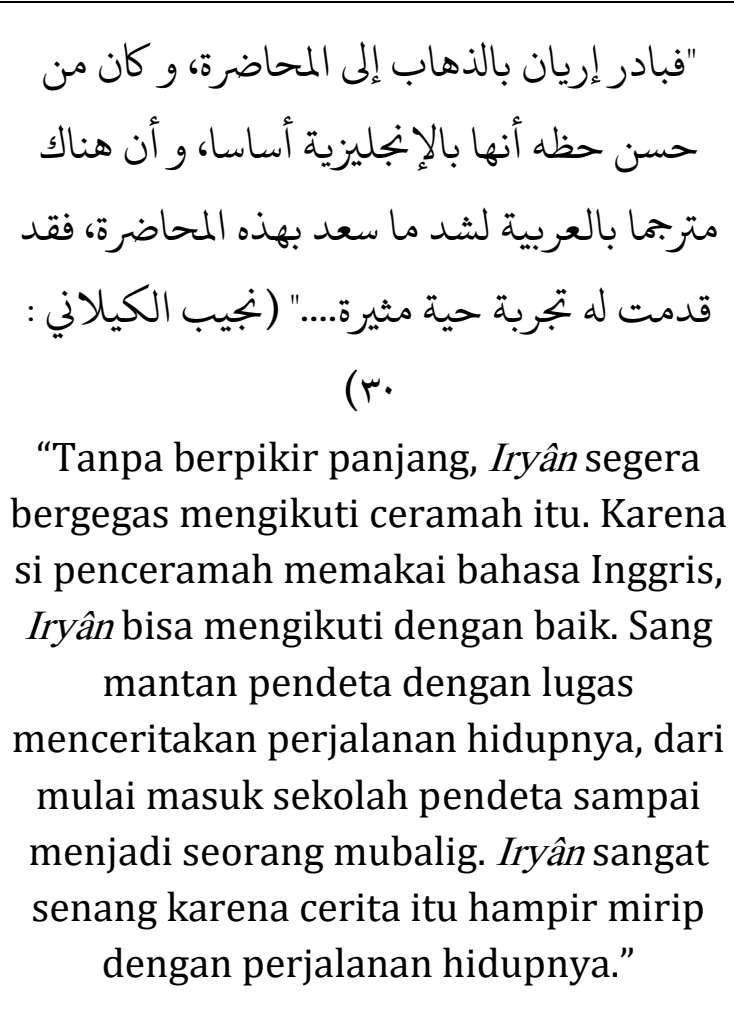 & Ego & $\begin{array}{l}\text { Bentuk Ego berupa } \\
\text { penalaran. Setelah } \\
\text { memutuskan ingin } \\
\text { belajar Islam. Ia } \\
\text { mendapat berita dari } \\
\text { Ali bahwa ada ceramah } \\
\text { agama yang akan } \\
\text { menggunakan bahasa } \\
\text { Inggris. Ia pun berfikir } \\
\text { bahwa inilah } \\
\text { kesempatan emas } \\
\text { untuk dapat mengenal } \\
\text { Islam. Hal ini } \\
\text { dikarenakan ia akan } \\
\text { dapat memahami } \\
\text { bahasa yang digunakan } \\
\text { penceramah dengan } \\
\text { baik. }\end{array}$ \\
\hline 14 & 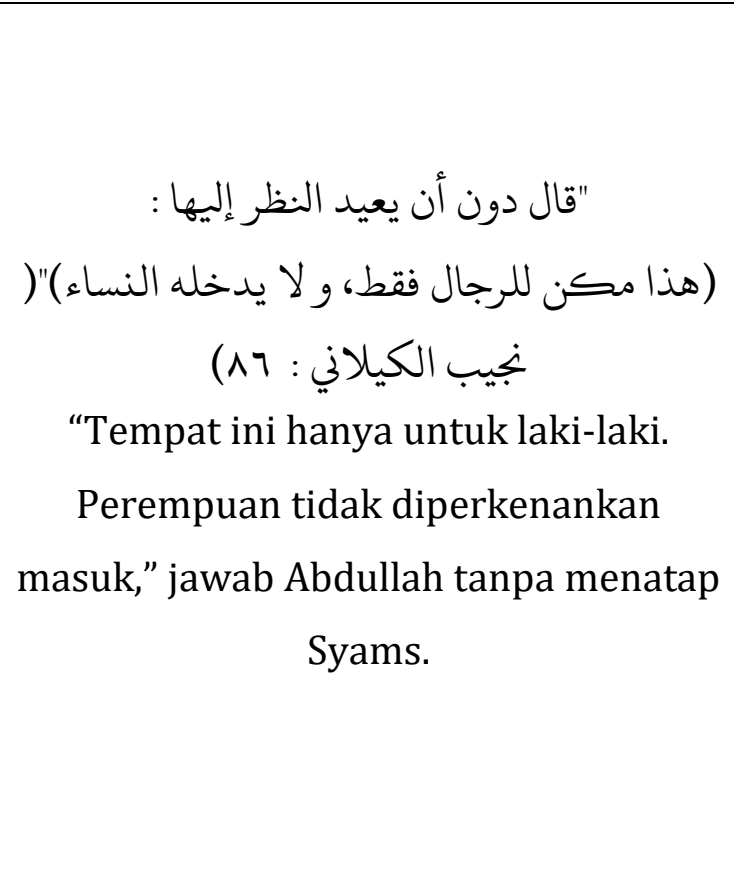 & Ego & $\begin{array}{c}\text { Bentuk Ego berupa } \\
\text { pengambilan } \\
\text { keputusan. } \\
\text { Setelah memutuskan } \\
\text { masuk Islam dan } \\
\text { mempelajarinya, Iryân } \\
\text { berupaya } \\
\text { mengamalkan ajaran } \\
\text { Islam dengan sebaik- } \\
\text { baiknya. Ia } \\
\text { memutuskan untuk } \\
\text { tidakk menuruti hawa } \\
\text { nafsunya. Dengan sadar } \\
\text { ia mengusir Syams yang } \\
\text { mendatanginya dengan } \\
\text { pakaian yang terbuka. }\end{array}$ \\
\hline
\end{tabular}




\begin{tabular}{|c|c|c|c|}
\hline 15 & 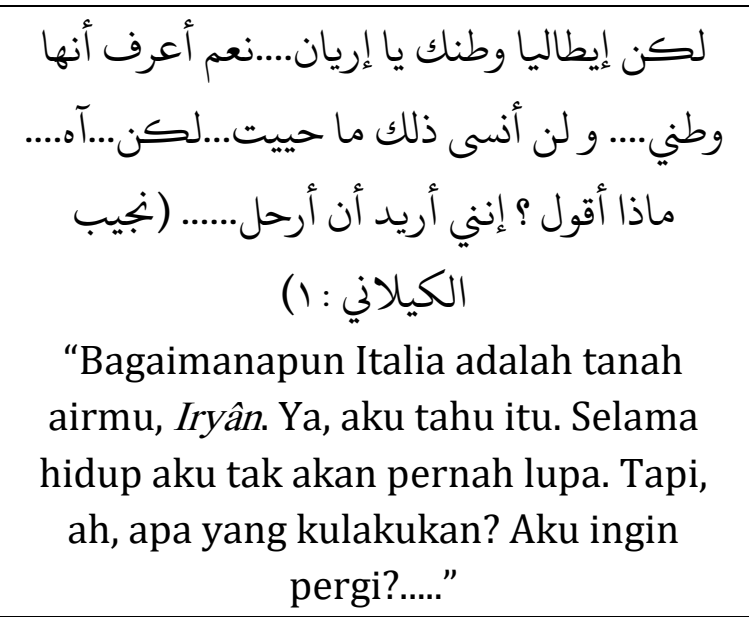 & Superego & $\begin{array}{l}\text { Superego selalu } \\
\text { berhubungan dengan } \\
\text { moralitas. Dalam hal ini } \\
\text { terjadi pertentangan } \\
\text { dalam diri Iryân, antara } \\
\text { pergi meninggalkan } \\
\text { Italia atau tetap di } \\
\text { Italia. Mengingat Italia } \\
\text { merupakan Tanah } \\
\text { kelahirannya. }\end{array}$ \\
\hline 16 & 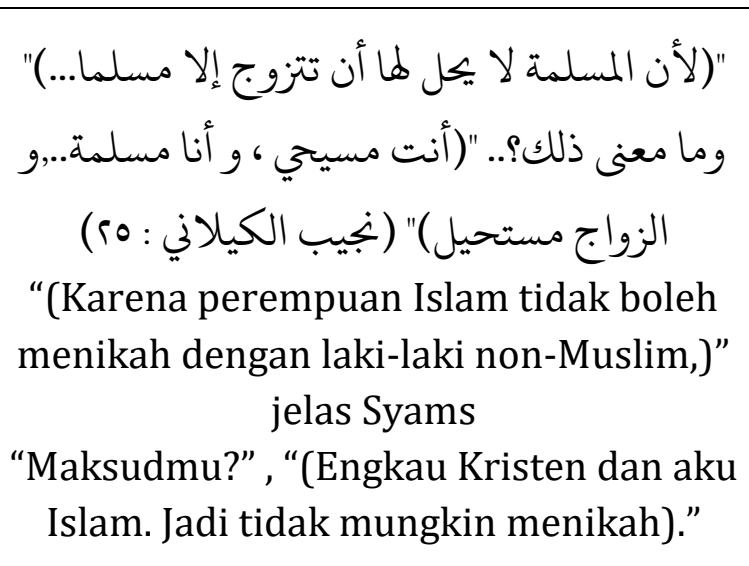 & Superego & $\begin{array}{l}\text { Dalam bentuk Superego } \\
\text { ini berhubungan } \\
\text { dengan permasalahan } \\
\text { agama. Yaitu ketika } \\
\text { Iryân seorang Kristen } \\
\text { tidak diperbolehkan } \\
\text { untuk menikahi Syams } \\
\text { merupakan seorang } \\
\text { muslimah secara } \\
\text { hukum agama Islam. }\end{array}$ \\
\hline 17 & 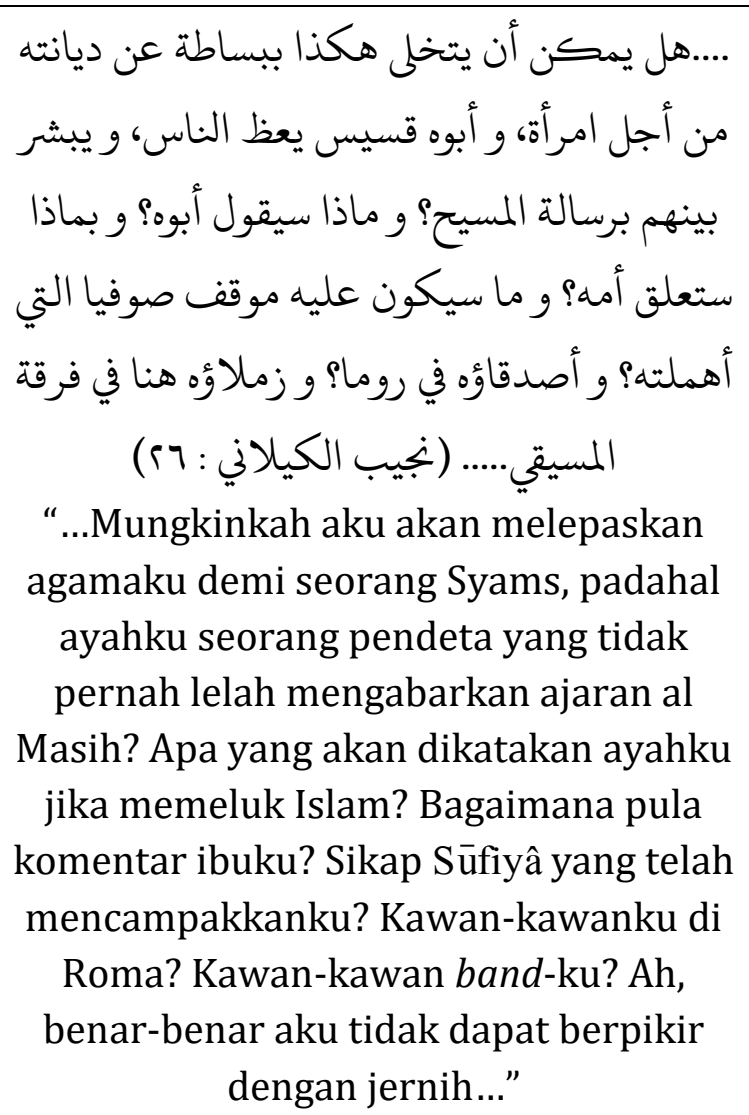 & Superego & $\begin{array}{l}\text { Superego Iryân yang ini } \\
\text { berhubungan hati } \\
\text { nurani, norma, dan juga } \\
\text { ajaran agama Kristen. } \\
\text { Ia ingin mempelajari } \\
\text { Islam, namun hatinya } \\
\text { menentang, apakah ia } \\
\text { akan melepas agama } \\
\text { lamanya hanya demi } \\
\text { wanita. Ia juga berpikir } \\
\text { tentang apa yang } \\
\text { dikatakan ayah, ibu, } \\
\text { serta teman-temannya. } \\
\text { Ayahnya yang seorang } \\
\text { penginjil pasti tidak } \\
\text { mengizinkan ia untuk } \\
\text { murtad dari agama } \\
\text { Kristen. }\end{array}$ \\
\hline
\end{tabular}




\section{Simpulan}

Hasil penelitian ini menyimpulkan bahwa ditemukan tiga pembagian psikis dalam struktur kepribadian pada tokoh Iryân dalam novel Al-Rojulu Al-Lazî Âmana karya Najib al-Kailani. Yaitu, ditemukan Id dengan delapan bentuk, Ego ada enam bentuk dan Superego dengan tiga bentuk. Bentuk Id yang ditemukan yaitu tentang dorongan seks dan yang paling dominan adalah memperoleh kedamaian hati melalui ajaran agama. Ego yang ditemukan lebih ke upaya memenuhi Id dengan melihat keadaan yang dialami Iryân. Bentuk Superego yaitu ketika hati nurani Iryân tergerak dan bergejolak ketika keinginan ke negeri timur dan mempelajari agama Islam itu terbentur dengan kondisi sosal di sekitar Iryân. Dapat disimpulkan bahwa bentuk Id merupakan psikis yang paling dominan dalam diri Iryân.

Teori psikologi sastra Sigmund Freud sebagai dasar tepat untuk membedah struktur kepribadian tokoh Iryân dalam novel Al-Rojulu Al-Lazî Âmana karya Najib alKailani. Hal ini menunjukan bahwa struktur kepribadian yang telah dirinci oleh Sigmund Freud terbukti lewat beberapa kutipan novel, sehingga penelitian menegaskan bahwa teori Sigmund Freud benar. Hal ini juga membuktikan betapa menariknya novel tersebut yang akan kepribadian tokoh yang bermacam-macam bentuknya.

\section{Daftar Pustaka}

Endraswara, Suwadi. Metode Penelitian Psikologi Sastra .Yogyakarata: Medpress, 2008.

Rokhmansyah, Alfian. Studi dan Pengkajian Sastra. Yogyakarta : Graha Ilmu, 2014. al-Kailani, Najib. Al-Rojulu Al-Lazî Âmana.. Lebanon : Resalah, 2005.

Minderop, Albertine. Psikologi Sastra. Jakarta : Pustaka Obor, 2018.

Shalih al-Arini, Abdullah bin. al-Ittijah al-Islamy fi< A'mal Najib al-Kailany alQosasiyyah. Riyad : Dar Kunuz Islibiya, 2005.

Freud, Sigmund. al-Mujaz fii Tahlil al-Nafsy. Maktabah Usroh, 2000.

Nurgiantoro, Burhan. Teori Pengkajian Fiksi. Yogyakarta: Gajah Mada University, 2009.

M. Hikmat, Mahi. Metode Penelitian: Dalam Perspektif Ilmu Komunikasi dan Sastra. Yogyakarta: Graha Ilmu, 2011. 
TSAQOFIYA: Jurnal Pendidikan Bahasa dan Sastra, 3 (1), 2021

Kuta Ratna, Nyoman. Teori, Metode, Teknik Penelitian Sastra. Yogyakarta: Pustaka Pelajar, 2015.

Khairani, Riztikha. "Analisis Klasifikasi Emosi Cinta Tokoh Laylâ dalam Novel alArwâhu al-Mutawarridah karya Khalil Gibran (Kajian Psikologi Sastra)," Jurnal Tsaqofiya-Jurnal Pendidikan Bahasa dan Sastra Arab, Vol. 2, No.2, 2020.

Khair, Rahimal. "Arketipe Ketaksadaran Tokoh Faris dan Inayah dalam novel Lail wa Qudbhan karya Najib Al-Kalani," Jurnal Arabiyatuna-Jurnal Bahasa Arab, Vol. 4, No.1, 2020.

Siompu, Nurjaliyah, "Tagyîr Syakhs\{iyah al-Asâsy fî al-Riwayah Al-Rojulu Al-Lazî Âmana li Najib al-Kailani (Dirasah Tah\{liliyah Sikulujiyah Adabiyah),". Skripsi, Jurusan Bahasa dan Sastra Arab, Universitas Islam Negeri Maulana Malik Ibrahim Malang, 2015. 